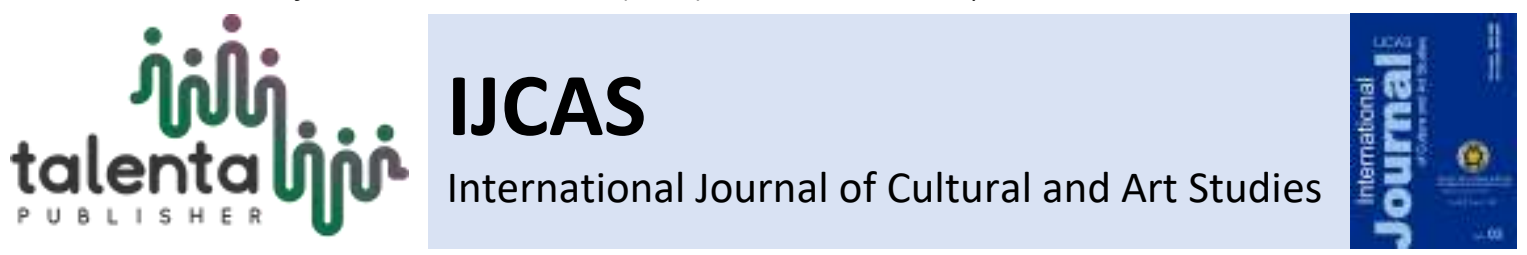

\title{
Ideology and Class Division in Veronica Roth's Divergent
}

\author{
Muhammad Kiki Wardana ${ }^{1 *}$, Sumita Roy ${ }^{2}$ \\ ${ }^{1}$ Department of English, Faculty of Language and Communication, Universitas Harapan Medan, Medan, \\ Indonesia \\ 2, Department of English, University College of Arts and Social Sciences, Osmania University, India
}

\begin{abstract}
The paper attempts to overview the ideology and the class division amongst factions in the novel. The ideology of the five factions in the future city of Chicago is embedded with self traits which dictates that everyone must fit into one dominant trait. The classification by traits or personalities makes clear provision that society will run as it is expected by the leader of the faction. The Divergent of Veronica Roth postulates the depiction of the utopia society that turns Dystopia by the insurgent led by Tris a character that possesses all the qualities and traits of the faction. The culture and the ideology of bourgeois and slave's society prevail vividly in the novel which is indicated by the ruling faction, Erudite as the bourgeois while the subjugated faction, Abnegation as the slave society. This paper utilizes the descriptive approach to meticulously break down the events by selecting and highlighting the occurrences in the novel as the way of obtaining the data. The theory of ideology by Raymond Williams (1977) was used in this paper to expose the core or base of cultural ideology amongst the classes. The paper finds out that the every faction has its own ideologies even though they were rooted from the same founding fathers.
\end{abstract}

Keyword: Divergent, Ideology, Aptitude Test, The Choosing Ceremony, Class Division, Faction.

Received 25 March 2019 | Revised 18 April 2019| Accepted 25 April 2019

\section{Introduction}

Literature rises as one of the media to convey human experience into the form of aesthetic experience which functions as the mirror to reflect and to ponder upon life. It is also understandable to comprehend literature as the form of society's struggle in fulfilling the basic needs. In the Marxism literature, the depiction of class division and struggles are vividly drawn. Man's real plight is to alleviate the class to become classless society as Barry [1] says that the aim of Marxism is to bring about a classless society, based on the common ownership of the means of production, distribution, and exchange.

\footnotetext{
*Corresponding author at: Department of English, Faculty of Language and Communication, Universitas Harapan Medan, Jl. Imam Bonjol No. 35, Medan city, Indonesia 
Therefore, the main tenet of most Marxist literature is based on the insurgent of the proletariat or the slave's society as the grass root society upon the misconduct and unfairness of the ruling class. Genre Dystopia as the rising star genre of its kind amongst the teenage readers captures the attention by bringing up the same issues. Debatable criticisms of the genre emerged in the 1960s, marked by the Chad Walsh's seminal study [2], From Utopia to Nightmare (1962). Walsh reuses The term dystopia from J. Max Patrick who uses it in 1952 in his anthology written with Glenn Negley entitled The Quest for Utopia: An Anthology of Imaginary Societies. [3]

\section{Divergent}

Divergent by Veronica Roth [5] brings about the divided society fragmented by faction which members are derived from the test that defines their destiny to be the member of the same faction of their parents or to be the faction betrayer by choosing another faction. The five factions called Abnegation the selfless, Erudite the smart, Candor the fair, Dauntless the brave, and Amity the kind. Every 16 year old member of the society is obliged to take the test that will define their faction. The test tells the trait that suits the faction. Most of the time, the new initiate faction members will have the same traits like their parents and choose the same faction like their parents' but there are case where the initiate's traits or personality fit into all factions, something that the ruling faction, Erudite, dislikes. Erudite believes this type of personality or The Divergent will take over the society due to the qualities of their traits. Having said that, Erudite altogether with Dauntless initiate the faction cleansing by hunting and killing the Abnegation faction which produces the Divergent personality the most.

\section{Ideology}

Marxism literature doesn't coin or generate the term ideology, but in every form of its literature, Marxism postulates ideology as part of the culture and ideas in the society. According to Williams [6] in a class society, all beliefs are founded on class position, and the systems of belief of all classes. Therefore the division of class in the society will eventually create different ideology. Taking the set in the futuristic Chicago of United States, the ambiance of Dystopia is very obvious. One of the features is crumbled American societies in the future that rebirth and re-established their nations from the perilous wars and natural calamities. The pattern is the founding father will elaborate new ideologies that they firmly believe would avoid the same tragedy happening again and these ideologies eventually being instilled and preserved amongst the civilians. Beatrice Prior, the protagonist says: 
Decades ago our ancestors realized that it is not political ideology, religious belief, race, or nationalism that is to blame for a warring world. Rather, they determined that it was the fault of human personality-of human kind's inclination toward evil, in whatever form that is. They divided into factions that sought to eradicate those qualities they believed responsible for the world's disarray" (Roth 32).

Many would believe that these are the right things to do, but there are also who eventually realize that some of the ideologies have gone wrong. Hence, they started to ignite the flame of revolution. At the beginning of the novel, the main character has strongly exposed how strong is her faction ideology shapes the way of thinking and behaviour of its followers. Beatrice Prior, whose faction is abnegation, looks into the mirror to do her hair and see her own reflection. Her faction allows its member to see their faces in the mirror only in the second day of every third month. According to her faction, seeing yourself in a mirror is something unnecessary and could create self indulgent. This is one of many ideologies that Beatrice holds before she decided to change her faction.

\subsection{Aptitude Test}

The American Dystopia society of future Chicago holds an ideology that to inaugurate someone into the state of maturity, he or she should undergo a test that will decide his/her entire life. This is called as Aptitude Test. The eligibility of this test is any boy or girl whose age is 16 years old. This aptitude test remains us into many civilizations in the world when someone enters the state of adulthood. In many cultures in Africa, a boy whose age is pretty enough to marry, should be able to hunt or kill a big animal. In one of the tribes in Indonesia, Nias ethnic, someone's maturity is defined by his ability to jump from a decent high rock. Eventually, the future society also emphasizes on the maturity test as one of the tests that would define his position in the society.

The only difference is, Dystopia society uses a high sophisticated technology to determine their faith. In Divergent, Aptitude test is conducted every year for every 16 year old teenager in the country to choose their humanist trait and quality. This test could only be administered by an officer that is not coming from their faction. So an abnegation child should be administered by someone who comes from dauntless faction or any other factions except abnegation. The test is conducted in a room consist of a reclining seat and other sophisticated technologies. Before the test begins, the participant shall drink the aptitude test serum that will make them unconscious and wake them up in an imaginary place. In this imaginary place, the test takes place. In the test, there would be things that participant fears of and things that participant should do to react from a trigger action. This will lead into participant's reaction in handling the fear. 
In Beatrice's test, she woke up in a mirror room. She furiously looked into herself that reflects in many angels of the room. Then suddenly she was befuddled by the presence of a seemingly angry dog. She also had to choose things like knife, cheese or meat as the respond of this simulation. In Beatrice's simulation case, she refused to choose any. Instead of taking meat, cheese or meat, she surrenders herself to the dog which indicates she possesses the trait of abnegation. In another simulation case, she saw an abnegation girl standing scarily in front of an angry dog that seemed very eager to attack her. Beatrice's respond to this case is very surprising. Instead of taking the knife and killing the dog, she chased the dog and calmed it. These traits were the traits of Dauntless and Abnegation.

For a common teenager, the simulation will only be resulting one quality that represents him/herself. Beatrice's result is very inconclusive. In the aptitude test, she showed remarkable traits from at least 3 factions which make her called The Divergent. The Divergent is something considered as taboo to be talked and discussed in the public. Some people believe that The Divergent is just a myth, but there are also factions that feel threatened by The Divergent. They are Dauntless and Erudite. This is due to the false belief that The Divergent can't be controlled because basically each member of the faction has been conditioned to think and act in a certain way and they have made their members find a pattern of thoughts that stay and work that way. The Divergent is believe to possesses a super mind that can control many things, in short The Divergent is actually a super human but would be vanished if they are found out.

\subsection{The Choosing Ceremony}

"Welcome to the choosing ceremony. Welcome to the day we honour the democratic philosophy of our ancestors, which tells us that every man has the right to choose his own way in this world" (Roth 31).

The choosing ceremony is the continuation of the aptitude test. This event is very important for everyone in the society because from this moment and onward, they will determine their faith, once they choose a faction, he couldn't turn back, so every teenager will deliberately decide their choice of their faction. The aptitude test helps them to know their trait, most of the time these juveniles will follow the result of the aptitude test in the choosing ceremony, But there are also who will decide to transfer to other faction, regardless what they got in the aptitude test. 
For Beatrice Prior, this is the most defining moment in her life. There is a struggle in her mind that really pressures and bothers her. Born from an Abnegation family, she sometimes doesn't feel really selfless. She feels she doesn't belong to her own faction. Strengthened by the result of the aptitude test that she knows from the test- taker, she finds herself befuddling about the "inconclusive" result. She event did not tell the result to her parents or her brother because the care taker reminded her firmly that her result is not to be known by anyone even her family.

When Beatrice asked the care taker what faction should she choose, the care taker of the test named Torry, who is a dauntless member told her to stay in her own faction. But Beatrice's feeling toward herself and her faction couldn't be hid. Once she says "When I look at the abnegation lifestyle as an outsider, I think it's beautiful. When I watch my family move in harmony; when we go to dinner parties and everyone cleans together afterward without having to be asked; when I see Caleb help strangers carry their groceries, I fall in love with this life all over again. Its only when I try to live it myself that $i$ have trouble. It never feels genuine" (Roth 24).

Being Abnegation has always been not genuine for Beatrice, but she also thinks about her family, how it feels for her parents if she chooses faction that is not her faction in the choosing ceremony. In the day of choosing ceremony, all the eligible teenagers from the five factions will be gathered in The Hub, the hundred floor building where the choosing ceremony takes place. Every year, one faction will responsible to hold the choosing ceremony. This time, Beatrice's faction, Abnegation, has been chosen to run this. Inside the hall of The Hub, every teenager who is eligible for The Choosing ceremony will be accompanied by their parents, so does Beatrice who is accompanied by her parents and her brother, Caleb, who is also eligible for The Choosing Ceremony, since his age is more or less 16 years old.

In the hall, Marcus Eaton, the leader or Abnegation delivers the speech about the foundation of their society. He says "decades ago our ancestors realized that it is not political ideology, religious belief, race, or nationalism that is to blame for a warring world. Rather, they determined that it was the fault of human personality-of human kind's inclination toward evil, in whatever form that is. They divided into factions that sought to eradicate those qualities they believed responsible for the world's disarray" (Roth 32). This is once again reminds us that the society where Beatrice lives in is actually entrenched by a very strong ideology.

When her brother's name being called, Beatrice feels unease, because one day before The Choosing Ceremony, Calleb told Beatrice to prioritize the family but looking up to their desire is more important. Calleb went to the stage where he should cut his palm with knife 
and drop one single blood into one of the five metal bowls that each represents substance symbol of faction. Grey stone for Abnegation, Dirt for Amity, Water for Erudite, Hot.Coal for Dauntless and Class for Candor. Without any hesitant, Calleb drop his blood on the water, which is Erudite. Beatrice herself took a very deep breath, after knowing her own brother would leave their family, taking a complete change, faith and destiny for the rest of his life, and will not be able to go back again to the family. Her brother chooses a new family.

Beatrice stepped up to the stage when her name was being called. There was a silent moment in herself and her parents of course. She walked through the isle with deliberate steps. She took the knife and cut her palm. She put her hand between the bowl of abnegation and dauntless. She felt confused, but she had to choose, she had to make decision. Deliberately her first blood dropped on the hot coal. She chose Dauntless. She left Abnegation. She left her family

\subsection{Class Division}

Obviously, the concept of class division in this novel is very much different with the definition of class itself. In The Hunger Games, class is divided based on districts that characteristically specialized into any kind of material or economy production, but not in Divergent. According to Wright [7], "Classes are social categories sharing subjectivelysalient attributes used by people to rank those categories within a system of economic stratification". With this definition of class, the actual content of these evaluative attributes will vary considerably across time and place. In some contexts, class-as-subjectiveclassification will revolve around life styles, in others around occupations, and in still others around income levels. Sometimes the economic content of the subjective classification system is quite direct - as in income levels; in other contexts, it is more indirect, as in expressions such as "the respectable classes", the "dangerous classes" (Wright 1)

The most important thing is, class is defined by the view of the people within the society about their subjective understanding of other people, judged from the strata social or ranking within the society itself. Class, in this sense of the word, would be contrasted to other forms of salient evaluation - religion, ethnicity, gender, occupation, etc. - which may have economic dimensions but which are not centrally defined in economic terms. This pejorative view must not be matched with what's happening within the society where Beatrice live.

\subsection{Faction}

There are five factions that coexist in this novel. In the opening of The Choosing Ceremony, one of Abnegation Leaders, Marcus Eaton, briefly describes the qualities of 
these five factions. "Working together, these five factions have lived in peace for many years, each contributing to a different sector of society. Abnegation has fulfilled our need for selfless leaders in government; candor has provided us with trustworthy and sound leaders in law; erudite has supplied us with intelligent teachers and researchers; amity has given us understanding counsellors and caretakers; and dauntless provides us with the protection from threats both within and without. But the reach of each faction is not limited to these areas. We give one and another far more than can be adequately summarized. In our factions, we find meaning, we find purpose, we find life" (Roth 36)

Her brief depiction about the faction leads us to the understanding that human has a dominant trait in himself. This trait, they believe is responsible in establishing human's relation with other. By concentrating and living the way this trait amalgamates in the society then a human will be keeping the inner peace that eventually will effect to the whole society.

\section{Conclusion}

Analytical Marxism approaches the issue by focusing on the scientific explication of Marx's analytical concepts, especially class. As laid out by Wright $(181$ - 182), there are four characteristics of Analytical Marxism: commitment to conventional scientific norms, emphasis on systematic conceptualization, explication of the steps and links between concepts within the theory, and importance given to the intentional actions of individuals. Most of these characteristics can be found in Wright's theory of class. First, commitment to scientific norms means that Wright values empirical research and is open to having his ideas and concepts modified by research. There are thus changes in the way Wright talks about class in the twenty years plus years he has been writing and his work is always a mixture of theory and research.

Peter Barry says: Marxism sees progress as coming about through the struggle for power between different social classes. This view of history as class struggle (rather than as for instance, a succession of dynasties, or as a gradual progress toward the attainment of national identity and sovereignty) regards it as 'motored' by the competition for economic, social and political advantage. Through all these references, definition, it is very obvious that Marxism has not always been talking about a classless society and fair economy system. Marxism is an ideology that has been twisted and turned into something political and the implementation is somehow can be seen in class domination. Class domination is economic, political, and culturalin other words, it has many different and related facets; and the struggle against it is similarly varied and complex. [4]. Of course this class domination has been sprung not only in the recent years where capitalist system dominating but also in the Dystopia scene. 


\section{REFERENCES}

[1] P. Barry, Beginning Theory: An Introduction to Literary and Cultural Theory. Manchester England: Manchester UP, 1995. Print.

[2] W. Chad, From Utopia to Nightmare. New York and Evanston: Harper \& Row, 1962. Print.

[3] N. Glenn and J. Max Patrick, eds., The Quest for Utopia: An Anthology of Imaginary Societies, New York: Henry Schuman, 1952. Print.

[4] R. Miliband, Marxism and Politics. London: Merlin, 2004. Print.

[5] V. Roth, Divergent. Channahon, IL: Library, 2014. Print.

[6] R. Williams, Marxism and Literature. Oxford England: Oxford UP, 1977. Print.

[7] E.O. Wright, Approaches to Class Analysis. Cambridge, UK: Cambridge UP, 2005. Print.

[8] E.O. Wright, Class, Crisis, and the State. London: NLB, 1978. Print.

[9] E.O. Wright, Classes. London: Verso, 1985. Print. 